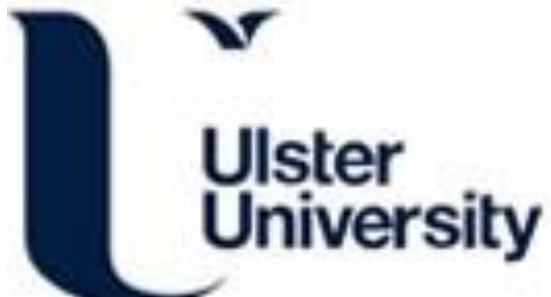

\section{The influence of emittance of low-emittance coating on the thermal performance of triple vacuum glazing}

Fang, Y., Hyde, T., \& Hewitt, N. (2010). The influence of emittance of low-emittance coating on the thermal performance of triple vacuum glazing. In Unknown Host Publication (pp. 921-928). International Association of Science and Technology for Development.

http://www.actapress.com/PaperInfo.aspx?PaperID=40942\&reason=500

Link to publication record in Ulster University Research Portal

\section{Published in:}

Unknown Host Publication

Publication Status:

Published (in print/issue): 01/07/2010

\section{Document Version}

Publisher's PDF, also known as Version of record

\section{General rights}

Copyright for the publications made accessible via Ulster University's Research Portal is retained by the author(s) and / or other copyright owners and it is a condition of accessing these publications that users recognise and abide by the legal requirements associated with these rights.

\section{Take down policy}

The Research Portal is Ulster University's institutional repository that provides access to Ulster's research outputs. Every effort has been made to ensure that content in the Research Portal does not infringe any person's rights, or applicable UK laws. If you discover content in the Research Portal that you believe breaches copyright or violates any law, please contact pure-support@ulster.ac.uk. 


\title{
THE INFLUENCE OF EMITTANCE OF LOW-EMITTANCE COATING ON THE THERMAL PERFORMANCE OF TRIPLE VACUUM GLAZING
}

\author{
Yueping Fang, Trevor J. Hyde, Neil Hewitt \\ School of the Built Environment, University of Ulster, BT37 0QB, \\ Newtownabbey, Northern Ireland, UK \\ Email: y.fang@ulster.ac.uk
}

\begin{abstract}
The thermal performance of the triple vacuum glazing was simulated using a finite volume model. The simulated triple vacuum glazing comprises three $4 \mathrm{~mm}$ thick glass panes with two vacuum gaps, with one to four internal glass surfaces coated with a low emittance (lowe) coating. The two vacuum gaps are sealed by an indium based sealant and separated by an array of stainless steel pillars with a height of $0.12 \mathrm{~mm}$ and a diameter of 0.3 $\mathrm{mm}$ spaced at $25 \mathrm{~mm}$. The simulation results show that increasing the emittance of the low-e coatings from 0.03 to 0.18 increases the total glazing heat transmission Uvalue by $50 \%$ for a $0.5 \mathrm{~m}$ by $0.5 \mathrm{~m}$ triple vacuum glazing; while for $1 \mathrm{~m}$ by $1 \mathrm{~m}$ triple vacuum glazing, the U-value is increased by $36 \%$. The centre-of-glazing U-value for both sizes is increased by $134.6 \%$. The simulation results indicate that when using three low-e coatings in the triple vacuum glazing, the vacuum gap with two low-e coatings should be set to the direction facing the hot side environment, while the vacuum gap with one coating should face the cold environment. When using two low-e coatings in the triple vacuum glazing, the U-value of the total triple vacuum glazing with one low-e coatings in each of the vacuum gaps is $10.3 \%$ less than that with two low-e coatings in the outdoor side vacuum gap and 3.47\% less than that with two low-e coatings in the indoor side vacuum gap. One coating should be set in both vacuum gaps rather than both coatings in the same vacuum gap.
\end{abstract}

\section{KEY WORDS}

Triple vacuum glazing, low-emittance coating, thermal performance, finite volume model

\section{Introduction}

The concept of vacuum glazing was first patented by Zoller, 1913 [1]. Since the first patent [1] was published nearly 90 years ago, there have been many patents about vacuum glazing published. However the first successfully fabricated vacuum glazing was reported by a team of the University of Sydney in 1989 which used a solder glass with a melting point of $450{ }^{\circ} \mathrm{C}$ to seal the periphery of the vacuum gap [2]. Collaborating with Baechli [3] the Fraunhofer Institute for Solar Energy Systems [4] successfully developed an edge seal for vacuum glazing based on a sputtered metallic layer and a soldering technique, but this work has not been published in a scientific journal.

Using the method developed by the University of Sydney, Samples up to $1 \mathrm{~m}$ by $1 \mathrm{~m}$ with a heat transmission (U-value) of $0.80 \mathrm{~W} \cdot \mathrm{m}^{-2} \cdot \mathrm{K}^{-1}$ in the centre-ofglazing area have been successfully produced in the laboratory [5]. Due to this high fabrication temperature, some soft coatings cannot be applied in this method. The optimisation of the minimal number and smallest diameter of support pillars (which determines the heat conduction through the pillar array) under the level of bearable stress exerted by atmospheric pressure on the glazing system was taken when designing vacuum glazing system. The second successful fabrication method was developed by a team of the University of Ulster [6, 7]. In the second method, an indium based alloy with a melting temperature of less than $200{ }^{\circ} \mathrm{C}$ was used as the edge sealant, thereby making the use of all soft coatings and tempered glass (which degrades at high temperature) possible. For samples of $0.4 \mathrm{~m}$ by $0.4 \mathrm{~m}$ a U-value of 0.9 $\mathrm{W} \cdot \mathrm{m}^{-2} \cdot \mathrm{K}^{-1}$ in the centre-of-glazing area has been achieved experimentally $[8,9]$.

To further reduce the heat transmission of vacuum glazing, a team of Swiss Federal Laboratories for Material Testing and Research [10] presented the viability of triple vacuum glazing. The mechanical design constraints were investigated and a U-value of 0.2 $\mathrm{W} . \mathrm{m}^{-2} \cdot \mathrm{K}^{-1}$ in the centre-of-glazing area was predicted when using a stainless steel pillar array with diameter of $0.3 \mathrm{~mm}$ and four low-emittance (low-e) coatings within two vacuum gaps. Based on the finite volume model which has been experimentally validated using the double vacuum glazing samples $[8,9]$, a threedimensional finite volume model was developed to simulate the thermal performance of the entire triple 
vacuum glazing with the support pillar arrays within the two vacuum gaps incorporated and modeled directly. The circular cross section of the pillar in a fabricated system is replaced by a square cross section pillar of equal area in the model. A graded mesh is used with a high density of nodes in and around the pillar to provide adequate representation of the heat transfer. Using this finite volume model, this paper investigated the effects of emittance of low-e coating on one to four glass surfaces in the two vacuum gaps of triple vacuum glazing. The numerical simulation results were compared with those calculated using the analytical model. In previous research on double vacuum glazing, this finite volume model has been employed to investigate the effect of hard and soft low-e coatings on the thermal performance of double vacuum glazing and experimentally validated [11].

\section{Nomenclature}

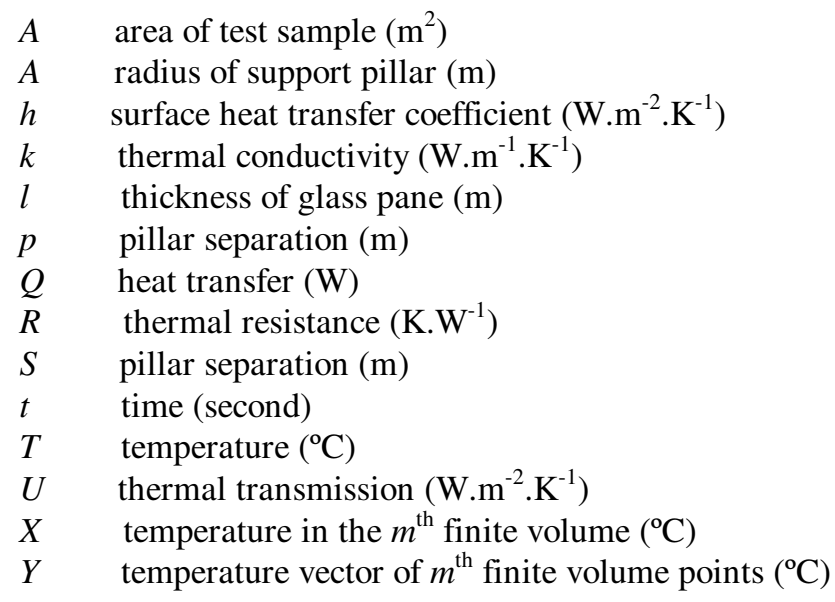

Greek letters

$\varepsilon \quad$ hemispheric emittance of a surface

$\sigma \quad$ Stefan-Boltzmann constant $\left(5.67 \times 10^{-8} \mathrm{~W} \cdot \mathrm{m}^{-2} \cdot \mathrm{K}^{-}\right.$

$\left.{ }^{4}\right)$

Subscripts

1, 2 refer to vacuum gaps 1 and 2 shown in Fig. 2

$I, I I, I I I$ refer to the first, second and third glass panes

$i, o \quad$ refer to warm and cold ambient temperatures

$j, k \quad$ refer to the glass surfaces

$g \quad$ glass

$m \quad$ glass pane number of the triple vacuum glazing

$n \quad$ vacuum gap number

$p \quad$ pillar

$r$ radiation

tot total resistance of triple vacuum glazing

\section{Heat Transfer through Triple Vacuum Glazing}

The schematic diagrams of triple vacuum glazing plan view and heat transfer mechanisms through the glazing are shown in Figs. 1(a) and 1(b). Both diagrams have different scales. The heat transfer through the glazing includes 1). heat flow from the warm side ambient to the glass pane at the warm side, involving radiation and convection; 2 ). radiation between the two glass surfaces within the two vacuum gaps; 3). conduction through the two pillar arrays and two edge seals within the two vacuum gaps; 4). Heat flow from the cold side glass pane to the cold side ambient by convection and radiation.

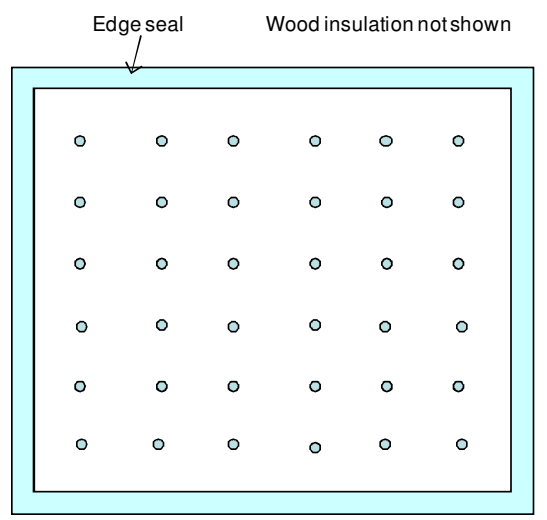

(a)

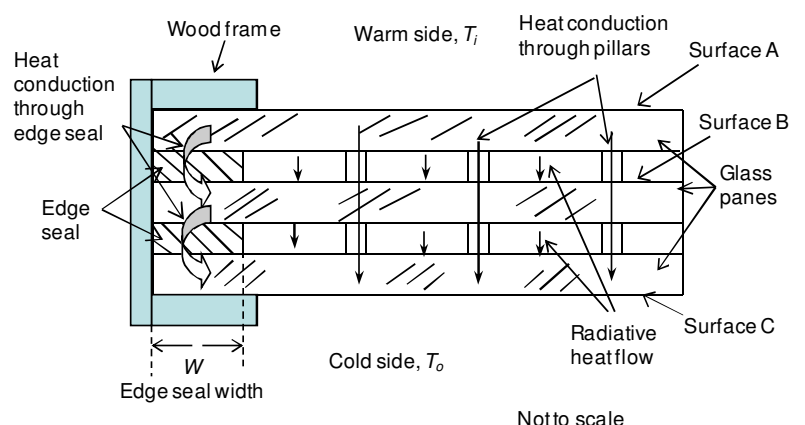

(b)

Fig. 1 (a) Plan view of the triple vacuum glazing in which the frame is not shown; (b) Schematic of heat flow through triple vacuum glazing. 1(a) and (b) are not to scale. 


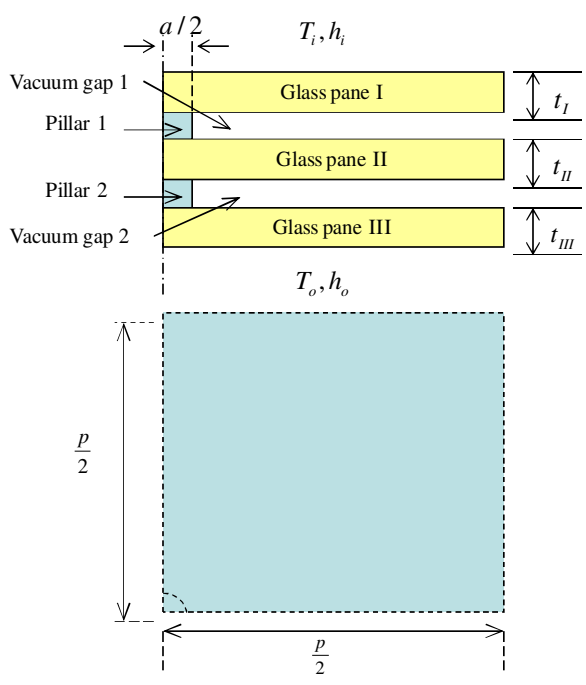

(a)

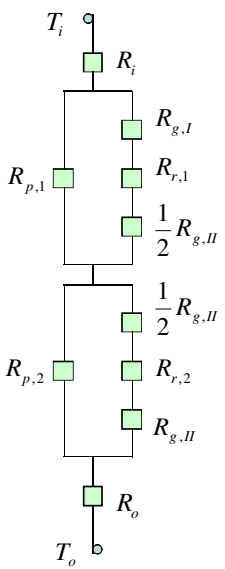

(b)
Fig. 2 (a) Cross section and plan view of a quarter of a unit cell and (b) thermal network of the unit cell at the central glazing area.

\section{Analytic model approach}

The heat transmission across a $25 \mathrm{~mm}$ by $25 \mathrm{~mm}$ cell with a pillar in the centre at the centre-of-glazing area was

investigated. Due to symmetry, a quarter of the cell is shown to represent the thermal network of a full cell, whose schematic diagram is shown in Fig. 2(a), in which a quarter of the pillar is shown at the corner of the square cell. The thermal network is shown in Fig. 2(b). The thermal resistance of each glass pane due to heat conduction is given by equation 1 :

$R_{g, l}=\frac{l_{m}}{k_{g} A}$

where $l_{m}$ is the thickness of the glass pane $m$, where $m$ $\in(I, I I, I I I), A$ is the area of the unit cell of the glazing; $k_{g}$ is the thermal conductivity of glass.

The thermal resistance due to radiative heat flow between the two glass surfaces within the two vacuum gaps is given by:

$R_{r, n}=\left(\frac{1}{\varepsilon_{j}}+\frac{1}{\varepsilon_{k}}-1\right)\left(4 \sigma T_{j k}^{3} A\right)^{-1}$

where $\varepsilon_{j}$ and $\varepsilon_{k}$ are the hemispheric emittance of the glass surfaces $j$ and $k$ opposite each other within the vacuum gaps 1 and 2; $\sigma$ is the Stefan-Boltzmann constant and $T_{j k}$ is the mean glass surface temperature in the vacuum gap in Kelvin. The thermal resistance due to heat conduction through the support pillars in vacuum gap $n$ (1 or 2$)$ is determined by equation 3 [5]:

$$
R_{p, n}=\frac{1}{2 k_{g} a}
$$

where $a$ is the radius of the cylindrical pillar. The thermal resistance of the middle glass pane is divided into two equal thermal resistances, the total thermal resistance between the outdoor and indoor glass pane surfaces is determined by equation 4 :

$$
R_{t o t}=\frac{R_{p, 1}\left(R_{g, 1}+R_{r, 1}+\frac{1}{2} R_{g, I I}\right)}{R_{p, 1}+R_{g, 1}+R_{r, 1}+\frac{1}{2} R_{g, I I}}+\frac{R_{p, 2}\left(R_{g, I I I}+R_{r, 2}+\frac{1}{2} R_{g, I I}\right)}{R_{p, 2}+R_{g, I I}+R_{r, 2}+\frac{1}{2} R_{g, I I}}
$$

The thermal resistances $R_{i}$ and $R_{o}$ at the indoor and outdoor glazing surfaces are the inverse of the surface the heat transfer coefficients, i.e. $R_{i}=1 / h_{i}$ and $R_{o}=1 / h_{o}$. The total heat transmission at the centre-of-glazing area is then given by [10]:

$$
U=\frac{1}{R_{i}+R_{t o t}+R_{o}}
$$

The heat flow through the entire triple vacuum glazing is the sum of heat flow across the centre-ofglazing area and the heat flow through the edge area including the heat conduction through the edge seal.

\section{Numerical Model Approach}

The finite volume model employed leads to a sparse well structured system of equations that can be efficiently solved. The basic equations used to develop the finite volume model can be found in a standard reference on the subject [12]. The governing equation used in the finite volume model is the heat diffusion equation as shown in equation 6 which is derived from consideration of Fourier's Law and the control volume (differential) surface areas:

$$
\frac{\partial^{2} T}{\partial^{2} x}+\frac{\partial^{2} T}{\partial^{2} y}+\frac{\partial^{2} T}{\partial^{2} z}=\frac{1}{\alpha} \frac{\partial T}{\partial t}
$$

where $T$ is the temperature of each finite volume of glass or support pillars, $t$ is the time parameter, $\alpha=k /(\rho c)$ is the thermal diffusivity, $k$ is the thermal conductivity, $\rho$ is the density and $c$ is the specific heat capacity of the material in the finite volume.

Assuming the view factor between the two internal surfaces within the vacuum gap to be 1 , the radiative heat 
transfer between the two surfaces is determined by equation 7:

$Q_{r}=\left(\frac{1}{\varepsilon_{j}}+\frac{1}{\varepsilon_{k}}-1\right)^{-1}\left(4 \sigma T_{j, k}^{3} A\right)\left(T_{j}-T_{k}\right)$

The boundary conditions (EN ISO 10077-1 [13]) are listed in table 1 .

Table 1 Boundary conditions of the triple vacuum glazing

\begin{tabular}{|c|c|c|}
\hline \multirow{2}{*}{$\begin{array}{c}\text { Ambient } \\
\text { temperature }\end{array}$} & Outdoor & $0{ }^{\circ} \mathrm{C}$ \\
\cline { 2 - 3 } & Indoor & $20^{\circ} \mathrm{C}$ \\
\hline $\begin{array}{c}\text { Glazing surface } \\
\text { heat transfer } \\
\text { coefficient }\end{array}$ & $\begin{array}{c}\text { External } \\
\text { surface }\end{array}$ & $25 \mathrm{~W} \cdot \mathrm{m}^{-2} \cdot \mathrm{K}^{-1}$ \\
\cline { 2 - 3 } & $\begin{array}{c}\text { Internal } \\
\text { surface }\end{array}$ & $7.7 \mathrm{~W} \cdot \mathrm{m}^{-2} \cdot \mathrm{K}^{-1}$ \\
\hline
\end{tabular}

The developed finite volume model implementation enables a large number of volumes to be employed to represent the vacuum glazing geometry and allows the direct representation of the small pillars. The equation bandwidth using the finite volume method is smaller than that obtained for the finite element method using 30 node brick elements and consequently requires fewer numerical operations and less CPU time to obtain a satisfactory solution.

The parameters of the simulated triple vacuum glazing are listed in Table 2. Due to symmetry conditions, only one quarter of the triple vacuum glazing was simulated to represent the whole glazing system under the boundary conditions of the EN ISO 10077-1 [13] experimental test. In the 3-D finite volume model, the support pillars were integrated and modeled into the complete system for ease of computation in the simulation. The cylindrical pillars employed in fabricated systems were replaced by the same number of cubical pillars with the same areas of cross section, since both pillar shapes conduct similar amounts of heat under the same boundary conditions [14]. The length of the square base of each cubical pillar is $\sqrt{\pi} a$, where $a$ is the radius of the equivalent cylindrical pillar. A graded mesh is used with a high density of nodes in and around each pillar to provide adequate representation of the heat transfer.

Table 2 Parameters of modeled triple vacuum glazing.

\begin{tabular}{|c|c|c|}
\hline \multicolumn{2}{|c|}{ PARAMETER } & VALUE \\
\hline $\begin{array}{c}\text { Vacuum glazing } \\
\text { dimensions }\end{array}$ & $\begin{array}{c}\text { Thickness, } \\
\text { width, length }\end{array}$ & $\begin{array}{c}12.24 \mathrm{~mm}, 0.5 \\
\mathrm{~m} \text { by } 0.5 \mathrm{~m}\end{array}$ \\
\hline $\begin{array}{c}\text { Glass pane } \\
\text { thickness }\end{array}$ & $4 \mathrm{~mm}$ \\
\hline Emittance & Four surfaces & 0.03 \\
\hline Edge seal width & & $6 \mathrm{~mm}$ \\
\hline
\end{tabular}

\begin{tabular}{|c|c|c|}
\hline Pillar diameter & & $0.3 \mathrm{~mm}$ \\
\hline Pillar height & & $0.12 \mathrm{~mm}$ \\
\hline Pillar separation & & $25 \mathrm{~mm}$ \\
\hline $\begin{array}{c}\text { Frame rebate } \\
\text { depth }\end{array}$ & $10 \mathrm{~mm}$ \\
\hline $\begin{array}{c}\text { Thermal } \\
\text { conductivity }\end{array}$ & Indium & $83.7 \mathrm{~W} \cdot \mathrm{m}^{-1} \cdot \mathrm{K}^{-1}$ \\
\cline { 2 - 3 } & $\begin{array}{c}\text { Glass \& solder } \\
\text { glass }\end{array}$ & $1 \mathrm{~W} \cdot \mathrm{m}^{-1} \cdot \mathrm{K}^{-1}$ \\
\cline { 2 - 3 } & Pillar & $20 \mathrm{~W} \cdot \mathrm{m}^{-1} \cdot \mathrm{K}^{-1}$ \\
\cline { 2 - 3 } & Wood frame & $0.17 \mathrm{~W} \cdot \mathrm{m}^{-1} \cdot \mathrm{K}^{-1}$ \\
\hline
\end{tabular}

In order to test the accuracy of simulations with specified mesh number, the thermal performance of a unit cell, with width $p=25 \mathrm{~mm}$ and with a single pillar in the centre, was simulated using a mesh of $85 \times 85 \times 30$ nodes. The 30 nodes ( $x$ direction) were distributed in a graded mesh through the glazing thickness of $12.24 \mathrm{~mm}$. The predicted thermal conductance of this simulated unit with a pillar in the centre was in good agreement with the analytical result calculated by equations 1 to 5 with a $1.8 \%$ variation which is comparable with the result $(2 \%)$ of Manz et al., [11]. With the same number of nodes $(85 \times 85)$ and distribution in the $y$ and $z$ directions on the glazing surface, and 20 nodes on the $x$ direction, the thermal transmission of double vacuum glazing at the centre-of-glazing was calculated to be $0.36 \mathrm{~W} \cdot \mathrm{m}^{-2} \cdot \mathrm{K}^{-1}$. This is same as the results of Griffiths et al., [5] and comparable to the result of Wilson et al [15]. This level of agreement indicates that the density of nodes is sufficient to simulate a realistic level of heat flow with high accuracy.

\section{INFLUENCE OF EMITTANCE OF LOW- EMITTANCE COATINGS}

With the boundary conditions and configuration parameters shown in Tables 1 and 2, the 3-D isotherms of the triple vacuum glazing (window frames not included), with four low-e coatings with emittance of 0.03 and 0.18 , were calculated and are illustrated in Figs. 3 and 4 respectively, which show the temperature gradient across the three glass panes due to the high thermal resistance of the two vacuum gaps. 


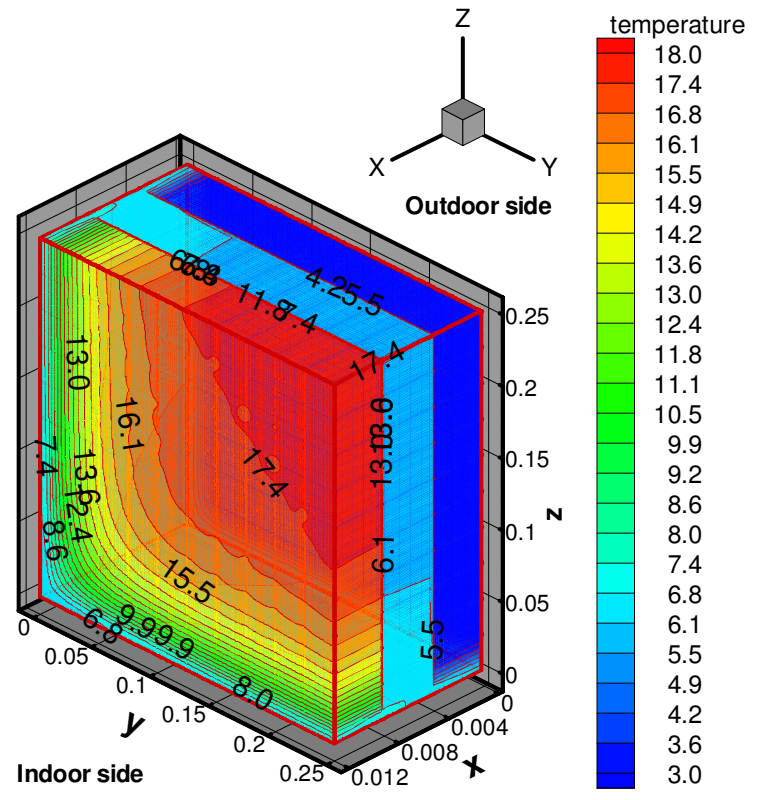

Fig. 3 Isotherms of triple vacuum glazing with boundary conditions and configuration parameters shown in Tables 1 and 2. The emittance of the four low-e coatings is 0.03 . The length unit of $\mathrm{X}, \mathrm{Y}, \mathrm{Z}$ axes is $\mathrm{m}$.

In Fig. 3 the mean surface temperature at the central glazing area on the indoor side glass pane is $17.4{ }^{\circ} \mathrm{C}$, the mean temperatures of the total indoor, middle and outdoor glass panes are $15.2{ }^{\circ} \mathrm{C}, 6.1{ }^{\circ} \mathrm{C}$ and $0.9^{\circ} \mathrm{C}$. The $\mathrm{U}$-value of the centre-of-glazing and total glazing areas are $0.26 \mathrm{~W} \cdot \mathrm{m}^{-2} \cdot \mathrm{K}^{-1}$ and $0.65 \mathrm{~W} \cdot \mathrm{m}^{-2} \cdot \mathrm{K}^{-1}$ respectively. The $\mathrm{U}$-value at the centre-of-glazing area of the triple vacuum glazing with the same configuration is similar to the result of Manz et al., [10]. The mean surface temperature difference between the indoor and outdoor glass panes is $14.3^{\circ} \mathrm{C}$. The mean surface temperature difference between the indoor and middle glass panes is $9.0^{\circ} \mathrm{C}$ and the mean surface temperature difference between the outdoor and middle glass panes is $5.3{ }^{\circ} \mathrm{C}$. In Fig. 4 the mean surface temperature at the central glazing area of the indoor side glass pane is $15.5^{\circ} \mathrm{C}$, the mean temperatures of the total indoor, middle and outdoor glass panes are $14.0^{\circ} \mathrm{C}, 7.0$ ${ }^{\circ} \mathrm{C}$ and $1.3^{\circ} \mathrm{C}$. The U-values of the centre-of-glazing and total glazing areas are $0.61 \mathrm{~W} \cdot \mathrm{m}^{-2} \cdot \mathrm{K}^{-1}$ and $0.95 \mathrm{~W} \cdot \mathrm{m}^{-2} \cdot \mathrm{K}^{-1}$ respectively. The mean surface temperature difference between the indoor and outdoor glass panes is $12.7^{\circ} \mathrm{C}$, the mean surface temperature difference between the indoor and middle glass panes is $7.0{ }^{\circ} \mathrm{C}$ and the mean surface temperature difference between the outdoor and middle glass panes is $5.7^{\circ} \mathrm{C}$.

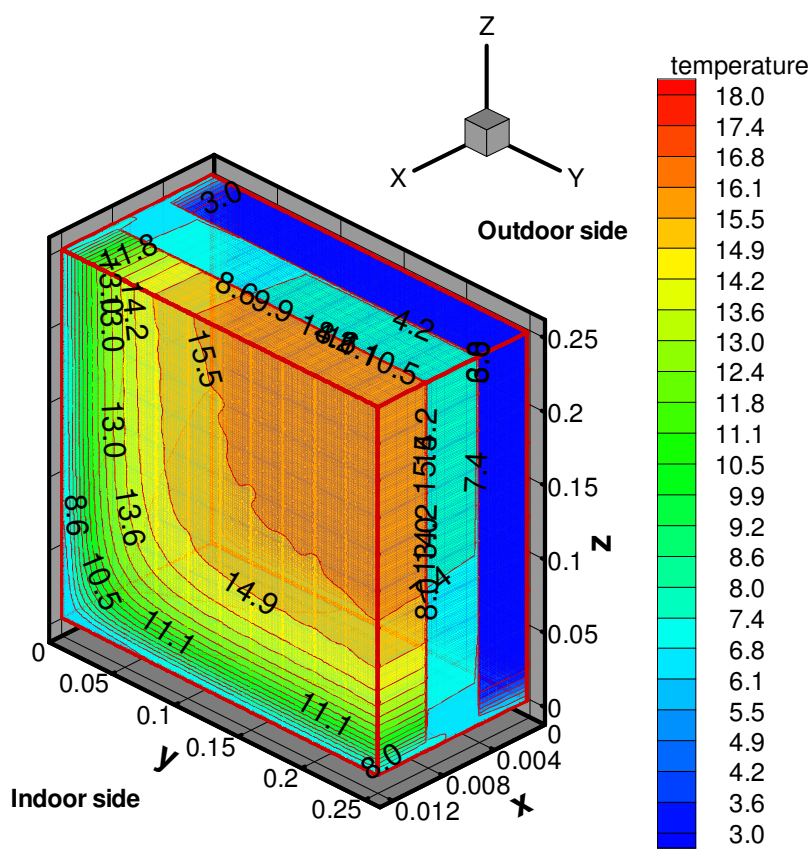

Fig. 4 Isotherms of triple vacuum glazing with boundary conditions and configuration parameters shown in Tables 1 and 2 . The emittance of the four low-e coatings is 0.18 .

In Figs 3 and 4 the temperature difference between the indoor and outdoor glass panes of the triple vacuum glazing with four 0.03 emittance low-e coatings is $1.6^{\circ} \mathrm{C}$ greater than that with four 0.18 low-e coatings. For both glazings with four 0.03 and 0.18 emittance low-e coatings, the temperature difference between the indoor and middle glass panes is greater than that between the middle and outdoor glass panes. Due to the relative significant influence of heat conduction through the edge seal, for triple vacuum glazing with four 0.03 emittance low-e coatings, the U-value of the entire glazing is $200 \%$ larger than that at the centre-of-glazing area; for that with four 0.18 emittance low-e coatings, the thermal transmission of the entire glazing system is $56 \%$ larger than that at the centre-of-glazing area.

The thermal performance of the triple vacuum glazing with a range of emittances for low-e coated glass panes were simulated and the results are shown in Fig. 5. The configuration parameters and boundary conditions are listed in Tables 1 and 2. Fig. 5 shows that by increasing the emittance of the low-e coating from 0.03 to 0.18 , the U-value at the centre-of-glazing area for both the $0.5 \mathrm{~m}$ by $0.5 \mathrm{~m}$ and the $1 \mathrm{~m}$ by $1 \mathrm{~m}$ triple vacuum glazing increases at the same rate by $134.6 \%$. The U-value of the total 0.5 $\mathrm{m}$ by $0.5 \mathrm{~m}$ triple vacuum glazing system increases by $50 \%$; while that of the total $1 \mathrm{~m}$ by $1 \mathrm{~m}$ triple vacuum glazing system increases by $36 \%$. The rate in increase of U-value of the total glazing system of the $0.5 \mathrm{~m}$ by $0.5 \mathrm{~m}$ triple vacuum glazing is greater than that of the $1 \mathrm{~m}$ by 1 $\mathrm{m}$ triple vacuum glazing due to the total heat conductance 
of the $0.5 \mathrm{~m}$ by $0.5 \mathrm{~m}$ glazing being larger than that of the $1 \mathrm{~m}$ by $1 \mathrm{~m}$ glazing.

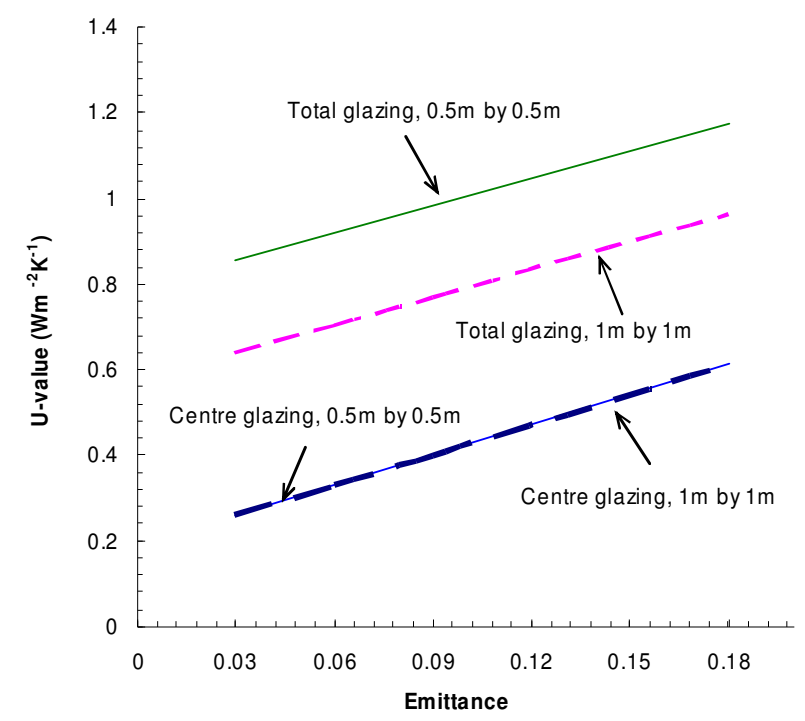

Fig. 5 U-value of the triple vacuum glazing with various emittance of low-e coatings. The configuration parameters are listed in Table 2 except emittance.

In the first stage of fabrication, a low-e coated glass of the type Pilkington K-glass will be used with one coating set in one of the two vacuum gaps and with two coatings in the other vacuum gap. In the simulation, two methods for setting the low-e coatings were considered. In method 1 , the vacuum gap with two low-e coatings was set to the outdoor (cold) side, the vacuum gap with one low-e coating at the indoor (hot) side. In method 2, the vacuum gap with two low-e coatings was set to the indoor side, the vacuum gap with one low-e coating at the outdoor side. The thermal performance of $0.5 \mathrm{~m}$ by $0.5 \mathrm{~m}$ triple vacuum glazing, with three coatings with an emittance of 0.18 set by methods 1 and 2 , were calculated and are shown in Fig. 6. For comparison, the thermal performance of triple vacuum glazing with four low-e coatings with emittance of 0.18 was calculated and is also presented in Fig. 6 .

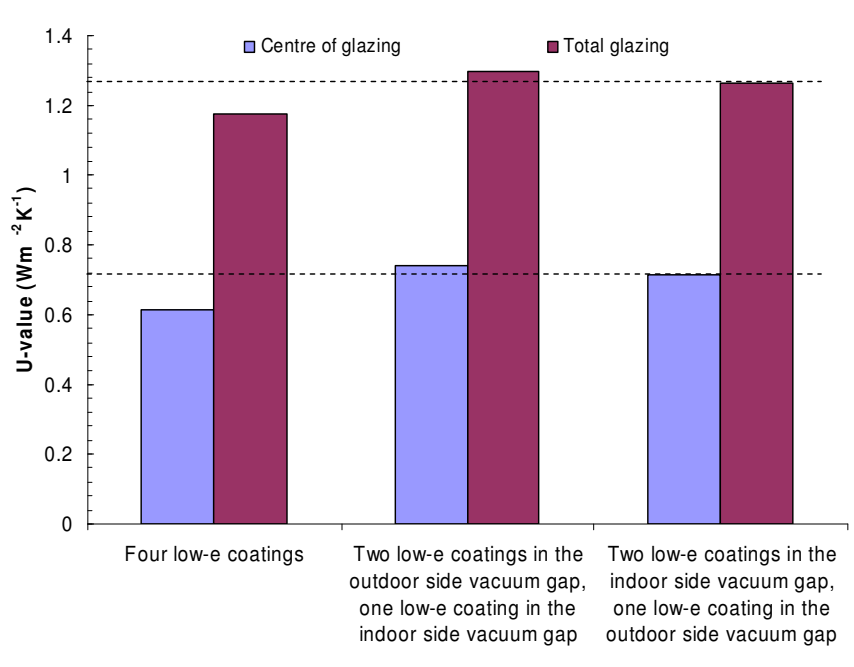

Fig. $6 \mathrm{U}$-values of $0.5 \mathrm{~m}$ by $0.5 \mathrm{~m}$ triple vacuum glazing with three and four low-e coatings with emittance of 0.18 in different vacuum gaps.

Fig. 6 shows that the U-value at the centre-ofglazing and total glazing areas of the triple vacuum glazing with three low-e coatings set by method 1 (the vacuum gap with two coatings at the outdoor side) is greater than that by method 2 (vacuum gap with two lowe coatings at the indoor side) by $3.36 \%$ and $2.85 \%$ respectively. Thus the vacuum gap with two low-e coatings should be set facing the indoor side. The U-value at the centre-of-glazing and total glazing areas of the triple vacuum glazing with three low-e coatings set using method 2 is larger than that with four low-e coatings by $16.63 \%$ and $7.47 \%$ respectively. The influence of the lowe coating on the centre-of-glazing area is clearly larger than that on the total glazing area, since the heat conduction through the edge seal compromises the influence on the total glazing area.

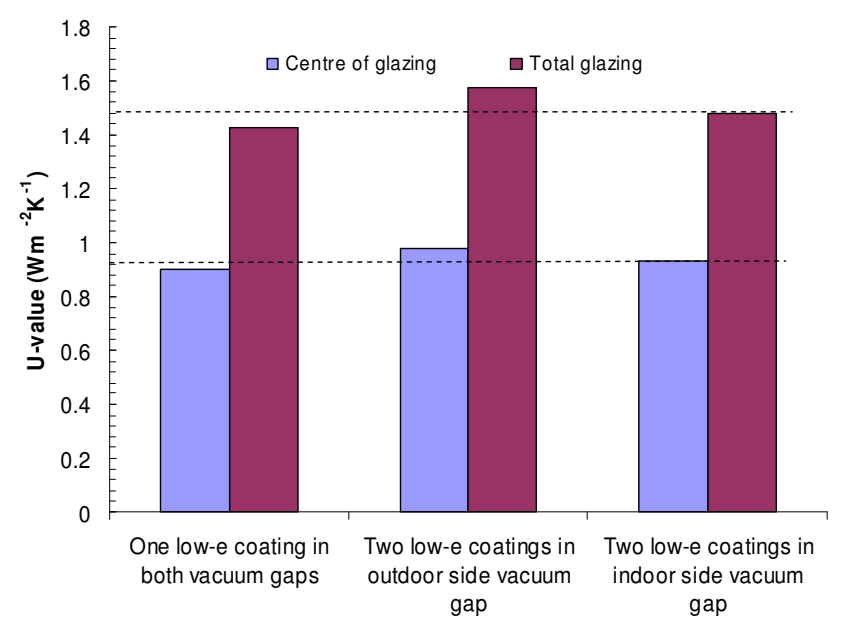

Fig. $7 \mathrm{U}$-values of $0.5 \mathrm{~m}$ by $0.5 \mathrm{~m}$ triple vacuum glazing with two low-e coatings. 
The U-values of triple vacuum glazings with two lowe coatings were calculated and are presented in Fig. 7 . Three setting cases of the two low-e coatings were considered. Case 1: one coating set in each of the two vacuum gaps; case 2: two coatings in one vacuum gap at the outdoor side; case 3: two coatings in the vacuum gap at the indoor side. Fig. 7 shows that the U-values of the centre-of-glazing and total glazing areas of the triple vacuum glazing in case 2 are larger than those of case 1 by $8.71 \%$ and $10.30 \%$; U-values of the centre-of-glazing and total glazing areas in case 3 are greater than those in case 1 by $3.52 \%$ and $3.47 \%$. The results indicate that when using two coatings in the triple vacuum glazing, it is best to set one coating in both of the vacuum gaps. The two vacuum gaps enhanced the efficiency of low-e coatings. If setting two low-e coatings in one vacuum gap, the vacuum gap with the two low-e coatings should be sent at the indoor side.

When using only one coating in the triple vacuum glazing, the U-values at the centre-of-glazing and total glazing areas were calculated and are presented in Fig. 8. Two cases were considered: case 1, the coating in the outdoor side vacuum gap; case 2: the coating in the indoor side vacuum gap. Fig. 8 shows that the U-values at the centre-of-glazing and total glazing in case 1 are larger than those in case 2 by $2.34 \%$ and $3.95 \%$ respectively.

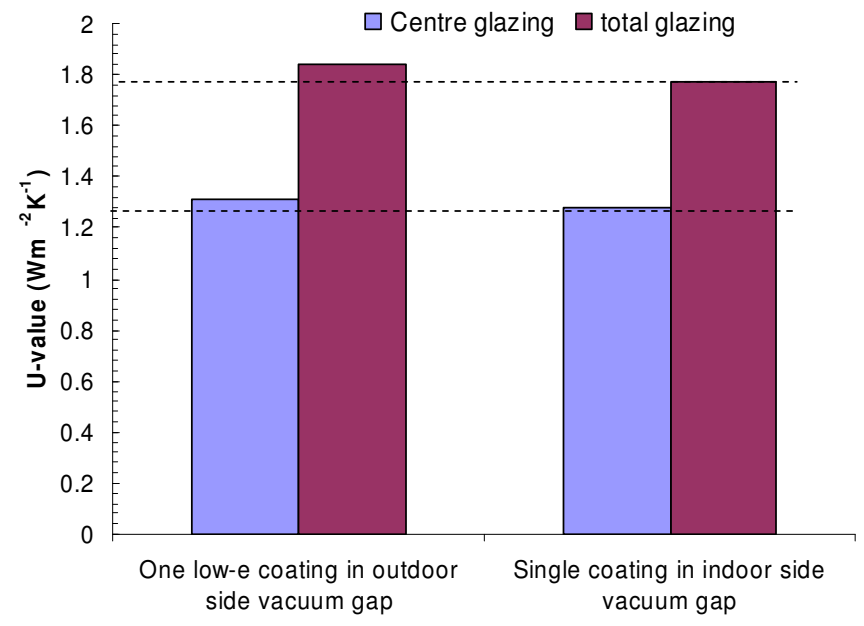

Fig. $8 \mathrm{U}$-value of $0.5 \mathrm{~m}$ by $0.5 \mathrm{~m}$ triple vacuum glazing with one low-e coating.

The U-values of the triple vacuum glazing with one, two, three and four low-e coatings are compared in Fig. 9, which shows that U-values at the centre-of-glazing and total glazing areas with three low-e coatings are larger than those with four low-e coatings by $16.63 \%$ and $7.47 \%$. The U-values at the centre-of-glazing and total glazing areas with two low-e coatings are larger than those with three low-e coatings by $25.63 \%$ and $13.1 \%$; Uvalues at the centre-of-glazing and total glazing areas with one low-e coatings are larger than those with two low-e coatings by $42.14 \%$ and $23.94 \%$. These results indicate that the use of a single low-e coating in the triple vacuum glazing significantly compromised the advantage of two vacuum gaps in the triple vacuum glazing.

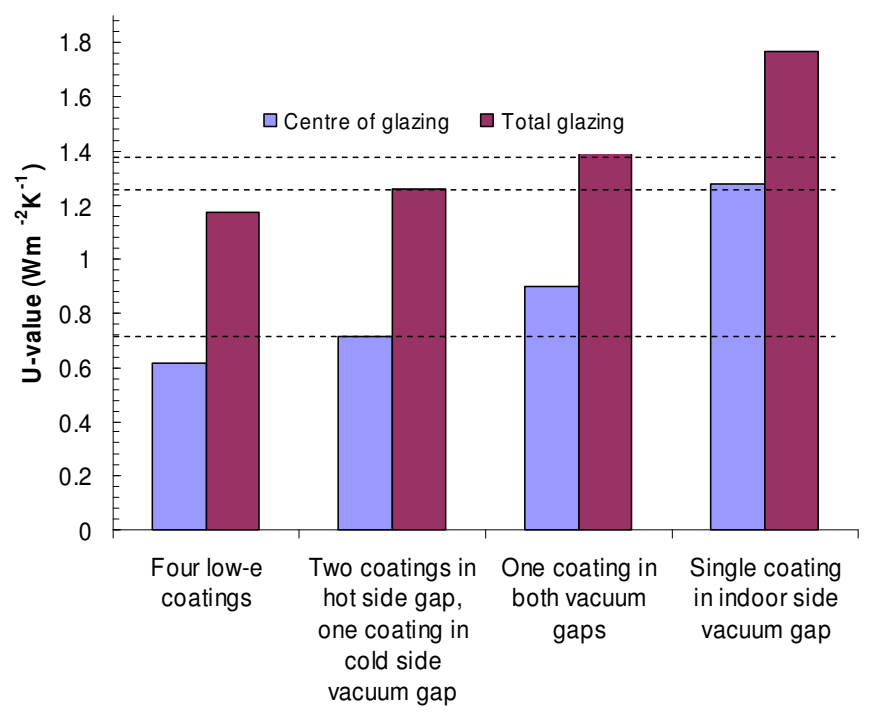

Fig. 9 Comparison of U-value of triple vacuum glazing with one, two, three and four low-e coatings.

\section{Conclusions}

The influence of emittance and location of low-e coatings within the vacuum gap of the triple vacuum glazing were simulated using a finite volume model. The results show that for $0.5 \mathrm{~m}$ by $0.5 \mathrm{~m}$ triple vacuum glazing, the U-value of the total glazing system with emittance of 0.18 is $50 \%$ larger than that with an emittance of 0.03 ; while for $1 \mathrm{~m}$ by $1 \mathrm{~m}$ triple vacuum glazing system, the U-value of the total glazing system with emittance of 0.18 is $36 \%$ larger than that with an emittance of 0.03 . The U-value at the centre-of-glazing area for both the $0.5 \mathrm{~m}$ by $0.5 \mathrm{~m}$ and $1 \mathrm{~m}$ by $1 \mathrm{~m}$ triple vacuum glazing with emittance of 0.18 is $134.6 \%$ greater than that with emittance of 0.03 . With increasing the emittance of low-e coating, the rate in increase of U-value of the total glazing system of the $0.5 \mathrm{~m}$ by $0.5 \mathrm{~m}$ triple vacuum glazing is greater than that of the $1 \mathrm{~m}$ by $1 \mathrm{~m}$ triple vacuum glazing due to greater effect the increased heat conductance through the edge seal has on the total glazing U-value for smaller glazing sizes.

The simulation results show that if using three low-e coatings in triple vacuum glazing, the location of the lowe coatings is important. When the vacuum gap with two low-e coatings is facing the indoor (hot) side and the vacuum gap with one low-e at the outdoor (cold) side, the 
U-values of the centre-of-glazing and total glazing areas are less by $3.36 \%$ and $2.85 \%$ than those when the vacuum gap with two low-e coatings is facing the cold side, and the vacuum gap with one coating facing the indoor side. The U-value of the centre-of- glazing area is more sensitive to the location of the low-e coating than that of the total glazing system, since the heat conduction through the edge seal compromises the influence of low-e coating on the total heat flow through the total glazing system.

If using two low-e coatings in triple vacuum glazing, the U-value of the centre-of-glazing and total glazing areas with one coating in both sides of vacuum gap are $8.71 \%$ and $10.30 \%$ lower than those with two coatings in the outdoor side vacuum gap and $3.52 \%$ and $3.47 \%$ less than those with two low-e coatings in the vacuum gap at the indoor side. Setting one low-e coating in both vacuum gaps is significantly better than setting two coatings in the same vacuum gap. Setting two coatings in the indoor side vacuum gap can get better thermal performance than setting two coatings in the outdoor side vacuum gap. The use of a single low-e coating in triple vacuum glazing significantly compromised the advantage of two vacuum gaps, thus is not practical for the triple vacuum glazing applications.

\section{Acknowledgements}

The authors acknowledge the support from the Charles Parson Energy Research Awards through the National Development 2007-2013 of the Department of Communications, Marine and Natural Resources, Dublin, Ireland. The international travel grant from the Royal Academy of Engineering is appreciated.

\section{References}

[1] Zoller A., 1913. Hohle Glasscheibe. German Patent Application No. 387655.

[2] S. J. Robinson and R.E. Collins, Evacuated windowstheory and practice, ISES Solar World Congress, International Solar Energy Society, Kobe, Japan (1989).

[3] K. Sager-Hintermann, E. Baechli, Method and equipment for making heat-insulating construction and/or lighting element. European Patent No. 1221526 (2002).

[4] V. Wittwer, Private communicate, Fraunhofer Institute for Solar Energy Systems, Freiburg, Germany (2005).

[5] R. E. Collins, T. M. Simko, Current status of the sciences and technology of vacuum glazing, Solar Energy, 62, 189-213 (1998).

[6] P. W. Griffiths, Di M. Leo, P. Cartwright, P.C. Eames, P. Yianoulis, G. Leftheriotis and B. Norton, Fabrication of evacuated glazing at low temperature. Solar Energy 63, 243-249 (1998).
[7] T. J. Hyde, P. W. Griffiths, P.C. Eames and B. Norton, Development of a novel low temperature edge seal for evacuated glazing. In Proc. World Renewable Energy Congress VI, Brighton, U.K. pp. 271-274 (2000). [8] Y. Fang, P.C. Eames, B. Norton, T.J. Hyde, Experimental validation of a numerical model for heat transfer in evacuated glazing, Solar Energy 80, 564-577, (2006).

[9] Y. Fang, T.J. Hyde, N. Hewitt, P.C. Eames, B. Norton, Comparison of vacuum glazing thermal performance predicted by two and three-dimensional models and experimental validation. Solar Energy Materials and Solar Cells 93 1492-1498 (2009).

[10] H. Manz, S. Brunner, L. Wullschleger, Triple vacuum glazing: Heat transfer and basic mechanical constraints, Solar Energy, 80, 1632-1642 (2006).

[11] Y. Fang, P.C. Eames, B. Norton, T.J. Hyde, J. Zhao, J. Wang, Y. Huang, Low emittance coatings and the thermal performance of vacuum glazing. Solar Energy 81, 8-12 (2007).

[12] S. S. Rao, The finite element method in Engineering, Fourth ed. Elsevier, Butterworth Heinemann (2005).

[13] EN ISO 10077-1. Thermal performance of windows, doors and shutters - Calculation of thermal transmittance - Part 1: Simplified method. European Committee for Standardization CEN, Brussels (2000).

[14] J. P. Holman, Heat Transfer (SI Metric Edition), McGraw-Hill, (1989).

[15] C. F. Wilson, T.M. Simko and R.E.Collins, Heat conduction through the support pillars in vacuum glazing. Solar Energy, 63 (6), 393 - 406 (1998). 